\title{
DEBUNKING THE RELATIONSHIP BETWEEN LAW AND CAPITALISM: HOW CORPORATE GOVERNANCE FAILURES CONTRIBUTE TO THE FINANCIAL CRISIS IN INDONESIA?
}

\author{
Najmu Laila Sopian* and Muhammad Yahdi Salampessy**
}

\author{
* New York University School of Law, United States; ** Department of Administrative Law, Faculty of Law \\ Universitas Indonesia
}

\section{Article Info}

Received : 6 January 2016 | Received in revised form : 21 June 2016 | Accepted : 25 November 2016 Corresponding author's e-mail : nls370@nyu.edu/najmulaila.sopian@gmail.com,; yahdisampale@gmail.com

\begin{abstract}
The recent global financial catastrophe has raised questions about the relationship between corporate governance and the crisis. Many scholars attribute the crisis to the corporate failure and the Anglo-Saxon model of capitalism. Many of the literatures, however, tend to focus on examining the issue of financial crisis in the developed economy. Following up this line of literatures, this paper will extend the discussion of the role of corporate governance in financial crisis in the developing world. Using Indonesia as a case study, this paper will look at the evidence that has emerged from the recent financial crisis regarding the failures of corporate governance in addressing and preventing the crisis.
\end{abstract}

Keywords: Financial Crisis, Capitalism, Corporate Governance, Bank Century, Free Market.

\begin{abstract}
Abstrak
Bencana keuangan global yang terakhir menimbulkan pertanyaan mengenai hubungan antara tata kelola perusahaan dan krisis keuangan yang terjadi. Banyak penulis yang mengaitkan penyebab krisis tersebut dengan kegagalan perusahaan dan sistem kapitalisme model AngloSaxon. Meskipun demikian, banyak dari literatur yang ada cenderung hanya mengkaji isu krisis keuangan di negara-negara maju. Sejalan dengan litertur-literatur yang telah ada tersebut, tulisan ini akan melanjutkan pembahasan mengenai peran tata kelola perusahaan terhadap sebagai penyebab krisis keuangan di negara berkembang. Dengan menggunakan Indonesia sebagai negara studi kasus, tulisan ini akan meninjau bukti-bukti yang timbul dari krisis keuangan yang lalu terkait dengan kegagalan tata kelola perusahaan dalam mengatasi dan mencegah krisis.
\end{abstract}

Kata kunci: Krisis finansial, kapitalisme, tata kelola perusahaan, Bank Century, pasar bebas 


\section{INTRODUCTION}

The global financial crisis in 2007 - 2010 that follows the near and/or total collapse of many major banks and financial institutions raises concerns about the good governance practice of those corporations before and during the crisis. It also raises questions of how and to what extent do corporate governance failures contribute to financial crisis?

Many literatures have linked the failure of corporate governance to the financial crisis. ${ }^{1}$ The OECD, for example, takes the view that the lack of implementation of the principles of corporate governance was closely associated with corporate failures and the financial crisis. In this view, the problem lies on poor implementation of the key areas of corporate governance such as executive salary, risk management, board practices, and the exercise of shareholder rights. ${ }^{2}$

Another view asserts that the problem that resulting in financial crisis is deeper than merely about implementation of corporate governance. Rather, the problem is more systemic and fundamental that involves institutional arrangements underpinned the corporate governance and the market system. ${ }^{3}$ According to this view, by reducing the problem to purely an implementation issue, the OECD fails to identify the real problem in corporate governance that have led to the collapse of the financial industry and trouble the whole economy. Scholars such as Visser (2010) and Clarke (2009) point specifically to the widely accepted Anglo-American model of capitalism and criticize the underlying principles and assumptions of the system. The capitalist system permits and even encourages "greed" and excessive risks taken for "short-time maximization" that would eventually induce its own vulnerability and the collapse of the global financial institutions.

Milhaupt and Pistor are among scholars who observe corporate governance of particular countries through the lenses of crisis. ${ }^{4}$ According to them, corporate governance crises or scandals can be an excellent intellectual tool for understanding a country's system of governance including its complexity and vulnerability; the interrelationship between legal institutions and economic growth, and the possible directions for future reforms. Using empirical narratives from six corporate scandals in six countries, the authors conduct what they call "institutional autopsy," in which they investigate the relationship between legal system and the portion of economic system that is directly related to firms' structures and governance.

Many of the literatures, however, tend to focus on examining the issue of financial crisis in the developed economy. Following up this line of literatures, this paper will extend the discussion of the role of corporate governance in financial crisis in the developing world. Developing countries face different challenges to market economies, relative to the developed ones. Needless to say, they also have various

\footnotetext{
${ }^{1}$ William Sun, Jim Stewart and David Pollard, "Introduction: Rethinking Corporate Governance - Lessons from the Global Financial Crisis" in Corporate Governance and the Global Financial Crisis: International Perspective, eds., William Sun, Jim Stewart, and David Pollard (Cambridge University Press, 2011).

2 The OECD Steering Group on Corporate Governance Report, "Corporate governance and The Financial Crisis: Key Findings and Main Messages." June 2009, available at http://www.oecd.org/dataoecd/3/10/ 43056196.pdf, accessed 11 January 2016

${ }^{3}$ Sun, Stewart and Pollard, Corporate Governance, p. 7.

4 Curtis J. Milhaupt, and Katharina Pistor, Law and Capitalism: What Corporate Crises Reveals about Legal Systems and Economic Development Around the World (Chicago: the University of Chicago Press, 2008).
} 
levels of governance and legal enforcement capacities that could support or impede the market system.

This paper will look at evidence that has emerged from the recent financial crisis regarding the failures of corporate governance in addressing financial crisis. This paper will proceed as follows. First, we review the general critiques towards the capitalist market and the current model of corporate governance. Next, we draw together literatures on the relationship between law and capitalism and examine the economic consequences of legal mechanism particularly of those related to corporate governance. Following this review, we describe the corporate governance failure in Indonesia, focusing on the Bank Century bailout scandal in 2008-2009. We conclude this paper by a brief discussion on what we can learn from the financial crisis and some alternative explanations.

\section{LITERATURE REVIEW}

\section{A. The Financial Crisis and the Inherent Vice of Capitalism}

"The failure to foresee the timing, extent and severity of the crisis and to head it off, while it had many causes, was principally a failure of the collective imagination of many bright people, both in this country and internationally, to understand the risks to the system as a whole."

British Academy Forum, 20095

Many of scholars from range of disciplines have predicted the inevitability of crisis and even the collapse of the capitalist system. And yet, the causes of the demise of capitalism and the dynamics behind the process are conceptually quite varied. This section will briefly review the works of giant political scientist such as Marx, ${ }^{6}$ Schumpeter, ${ }^{7}$ and Polanyi, ${ }^{8}$ particularly on their critiques and vision towards capitalism.

Marx, Schumpeter, and Polanyi share a similar view on the inherent conflict operating within the capitalist mode of production that undermines its own institutional foundations. Modern capitalism allows for self-realization and encourages creativity, while at the same time limiting human freedom through the process of rationalization, alienation, and domination. All of them try to understand the source of this contradiction through different lenses: Marx with the theory of Alienation, Schumpeter with the theory of Creative Destruction, and Polanyi with the theory of Double Movement.

Marx attributes basic contradiction in society to capitalist mode of production characterized by the concentration of means of production in a particular class. This concentration is a result of the appropriation of economic surplus from labor

\footnotetext{
5 Roland Perez, "Finance, Governance and Management: Lessons to be Learned From The Current Crisis," in Corporate Governance

${ }^{6}$ Marx-Engels, Reader, Edited by Robert C. Tucker, Second Edition (W. W. Norton \& Company; 1978) 1950).

Joseph A. Schumpeter, Capitalism, Socialism and Democracy, Third Edition (New York: Harper \& Row,

8 Karl Polanyi, The Great Transformation: The Political and Economic Origins of our Time (Boston: Beacon Press, 1944).
} 
(the direct producer) by the capitalist (the capital owner). Capitalist system allows for domination over the have-not class by those who own and control the means of production. Capitalism displays structural instability due to continuous exploitation in the capital accumulation process that eventually will lead to crisis and revolt.

Schumpeter shares Marx's views that capitalism is doomed to failure. Schumpeter argues, however, it is precisely the success of capitalism, rather than its failure, that contributes to its own destruction. Schumpeter attributes the success of capitalist system lies in the fact that it encourages innovations and entrepreneurial activities. That is said, innovation and competition are the intrinsic nature of capitalism. ${ }^{9}$ According to Schumpeter, the entrepreneurs represent the dynamic element of capitalism, for they are the agent of innovation and change. Capitalism's dynamic system allows for a constant renewal of the capitalist class because the successful entrepreneurs will be able to become capitalist owners. Schumpeter views this process will eventually undermine the position of capitalist class because they are constantly under attack of external forces.

This condition leads Schumpeter to conclude that capitalism is an unstable system because it contains "the seed of their own destruction" from within. Under the capitalist system, the process of accumulation is continuously disrupted by "creative response" comes from the innovations of extraordinary individuals ("the entrepreneurs"). This creative disruption is the driving for social and economic changes because it brings novelties that can challenge the status quo.

Schumpeter views bureaucratization of large-scale corporation, which orientates toward stability and routinized business, will eventually undermine individual's creativity and spontaneity. The advancement of capitalism and the emergence of big corporations will followed by "adaptive response" in which innovation and creativity become institutionalized; it reduce the element of individual's spontaneity and allows for reproduction of innovation by specialists in routinized setting. Institutionalization of the creative disruption will lead to the replacement of "heroic" entrepreneurs who in fact are the source of capitalist's dynamism. The role of entrepreneurs and innovation become less important in the process of production following the increasing rationalization and mechanization in the economic life. In the long run, this process will result in the gradual disappearance of the entrepreneur and economic novelty and innovation, which ultimately lead to capitalist institutional collapse.

Another classic scholar, Polanyi, argues that the market society will collapse due a contradictory process called "double movement." Market society is characterized by the institutional separation between the political and the economic realms, which is unstable due to a contradictory process inherent in the system. Polanyi describes this contradiction using the notion of "double movement" which operates within the concept of economic embeddedness.

The double movement represents two contradictory features of the capitalist society as reflected in the tension between market expansion and countermovement to protect the general interest of the society. Protective countermovement is seen as social or institutional response in the form of resistance against detrimental effects of the market system that puts emphasis on individuality and rationalization. This struggle will lead to instability for it causes not only social disintegration but also

9 Mark Harvey and Stan Metcalfe, "The Ordering Of Change: Polanyi, Schumpeter and The Nature Of The Market Mechanism," Discussion Paper 70 March 2005, CRIC University Of Manchester, Available at: http://repository.essex.ac.uk/10408/1/polyani_schumpeter_amrket.pdf 
market failure as the result of constant interventionist tendencies to the accumulation process in the market system. Polanyi's argument is very interesting because it explains the needs for state intervention in regulating the market to protect the society from harm and crisis. This particularly relevant to the discussion of the government response to the current financial crisis that we will explore in the next section.

\section{B. Why Does the Capitalist System Persist and Endure the Crisis?}

As been discussed above, many of scholars from range of discipline such as Marx, Schumpeter, and Polanyi, have predicted the inevitability of crisis and even the collapse of the capitalist system. Yet, we witness that the capitalist system has been successfully recovered from its periodic crisis and is become stronger than ever. The question is, why?

Welfare State, defined as a peculiar mode of organizing economy and allocating resources, is arguably the reason why capitalism survives to this day. It is not a coincidence that the Welfare State becomes the common feature of all developed capitalist countries. Contrary to common belief, capitalist economy and welfare state can and do exist side by side. There are three reasons why social welfare program is important for the sustainability of the market society that will be discussed as follows.

First, government intervention in the market economy through various social welfare programs streams from the need to protect the society from harms resulted from market failure and crisis. Central to this idea is the needs to bring the state back into the economic realm, which idea contradicts libertarian notion that requires a minimum role of the state. The Welfare State represents Polanyi's inevitable "protective countermovement" and inevitable role of the government intervention to the market economy. Social welfare programs such as universal health care, labor protection, and free education can become a safety net, or "a powerful countercyclical tool" (Pierson) that would help to mitigate the immediate and severe impact of crises, as well as partially correct the market failure. These programs, therefore, are essential elements of the social and economic organization of capitalist democracies.

Secondly, the welfare state also has political significance. Social expenditure can help to dismantle social unrest and enhance the legitimacy of liberal democracy. Social programs can legitimate the taxation function of government because people will eventually enjoy and get benefit from the money they spend on taxes. It also provides a favorable condition for the emergence of interest groups that is essential for the working of democracy.

Lastly, social programs and "decommodification" of goods and services are essential in order to prevent social integration and stabilize the accumulation process in the market system. This view has important policy implications because now the debate is not on whether to regulate or not to regulate the economic activities, but on what kind of regulations we prefer for the economy.

The emergence of Welfare State has several implications. First, the Welfare State requires a more active and a greater role of the state in the economic and social life through regulations and sounds social policies. Being a Welfare State implies increasing the provision of public goods and expanding social protection. Consequently, the state needs more resources to collect tax money and to deliver services and goods for its people. Structurally, a broad role of the state means a big size of bureaucracy. A universal health care, for example, will not be realized if the State does not have 
enough civil servants to support the program, collect information about potential benefit receivers, and so on.

Welfare practices also have an impact on legal institutions. As a result, law serves a new function and structures in the welfare state as opposed to those of the liberal state. The interventionist nature of the welfare regulatory-state implies an instrumentalist use of law as a mean of social control. ${ }^{10}$ Teubner views the Welfare State represents a shift away from "autonomous law" towards "responsive law." ${ }^{11}$ Legal institutions emerge as a tool to serve the new function of state, which would have a bigger impact not only on legal structure, but also legal culture. It impacts public perception and expectation on roles that the state has to perform in order to promote and protect the sound and just social life.

\section{Bringing the State Back into The Economy}

"I am very troubled by the failure of Bear Stearns," he said, "and I do not like the idea of the Fed getting involved in a bailout of that company.... That is socialism, at least that's what I was taught."

- U.S. Senate Banking Committee members Jim Bunning in Too Big Too Fail ${ }^{12}$

Government intervention through bailout of the banking system might not a compelling idea in the world that is heavily influenced by libertarian economist, at least for the past fifty years. The liberal economy works under the assumption that the state and economy should be inherently separated from each other. Its proponent advocates the view that free market and deregulation as "the most efficient and rational way of allocating resources, monitoring corporations and disciplining corporate underperformance and misbehavior." 13 State's interventions are harmful because it would disrupt the market mechanism.

However, the key assumption of free market has long been criticized and the current financial crisis proves that under some conditions the state intervention is necessary to correct market failures that could harm the society. In this regard, it is fruitful to read the greater role of the state vis-à-vis the market within the larger historical framework provided by Karl Polanyi in his influential book, the Great Transformation (1944).

Contrary to the libertarians, Polanyi argued that there is "no such thing as free market" and the institutional separation between the economy and the politics is a "stark utopia." Polanyi rejects the very assumption of market economy characterized by commodification of the means productions including labor, land, and money ("fictitious commodities") and the total absence of state's intervention from economic activities. Polanyi argues that the doctrine of laissez-faire is based on a misleading understanding of the nature of political-economy relation, which he argues cannot and never be separated. He supports his claim by tracing back to the $18-19^{\text {th }}$ century European civilization, which leads him to believe that the history of market is actually

10 L. Friedman, "Legal Culture and the Welfare State" in Dilemmas of Law in the Welfare State ed. Gunther Teubner (Berlin: de Gruyter, 1986).

${ }^{11}$ Phillipe Nonet and Philip Selznick, Law and Society in Transition: Toward Responsive Law (New York: Harper and Row, 1978).

12 Andrew Ross Sorkin, Too Big to Fail: The Inside Story of How Wall Street and Washington Fought to Save the Financial System - and Themselves (New York: The Penguin Groups, 2009).

${ }^{13}$ Sun, Stewart, and Pollard, Corporate Governance 
the history of a planned economy for there is no such free market economy. This leads him to conclude that any attempt to realize market economy is essentially a "utopian" project.

Polanyi further argues that institutional separation between the political and the economic realms creates instability for it leads to a contradictory process inherent in the capitalist system. Polanyi describes this contradiction using the notion of "double movement" which represents two contradictory features of the capitalist society as reflected in the tension between market expansion and the "countermovement" to protect general interest of the society. Protective countermovement is seen as social or institutional response in the form of resistance against detrimental effects created by the market system that puts emphasis on individuality and rationalization. This struggle will lead to instability for it causes not only social disintegration but also the market failure. This contradiction, according to Polanyi, will eventually lead to institutional collapse of the market society.

Polanyi concludes by calling for the state back to regulate the market. Regulatory response to crisis including bailout represents "Polanyi's inevitable protective countermovement" and inevitable role of the government intervention to the market economy. This view has important policy implications because now the debate is not on whether or not there should be regulation on the economic activities, but on what kind of regulations do we prefer for the economy? This question leads us to the next discussion on corporate governance model as specific set of rules underpinning the market economy.

As previously discussed, the current financial crisis highlights deficiencies in the market-oriented approach typically associated with the Anglo-American corporate governance model. Efforts in increasing the number of "best practices," code of conducts and principles, do not contribute much in preventing a systemic failure of corporate governance. The market-oriented approach to corporate governance is characterized by "deregulation, self-regulation, the market for corporate control and other market discipline mechanisms, with governing activities driven by financialdominant incentives such as pure shareholder value, short-term profit maximization and managerial compensation." 14

In line with the above argument, Visser argues,

"We have been facing multifacets of greed permitted or encouraged by governmental policies, institutional arrangements, ideologies and cultures. Self-interest and incentive systems led to executive greed, leveraging and risk transfer led to banking greed, deregulation and speculation led to financial market greed, self-regulation and short-term profit maximization led to corporate greed, and shareholder capitalism led to capitalist greed."15

Clarke further criticize the Anglo-American corporate model because it "...has enabled, permitted or tolerated excess power and wealth at the hands of CEOs, and incentivized investment bank executives to pursue vast securitization and high leveraging to enrich themselves greedily at the severe cost of shareholders, investors

14 Thomas Clarke, "Corporate Governance Causes of the Global Financial Crisis," in Corporate Governance, p. 7.

15 Visser, W. 2010. “CSR 2.0: From The Age of Greed To The Age of Responsibility”, in Reframing Corporate Social Responsibility: Lessons from the Global Financial Crisis, eds. William SunJim Stewart,David (Bingley: Emerald Group Publishing, 2010); quote taken from: Sun, Stewart, and Pollard, Corporate Governance, p. 7. 
and other stakeholders."16 This type of corporate governance is believed to largely contribute to the global financial crisis.

\section{Corporate Crisis and the Economic Consequences of Law}

Over the past several decades, scholars have been trying to expound the divergent in cross-countries economic outcomes using various explanatory variables such as trade, technological advancements, policy choices, geographical endowments, human capitals, and cultures. Scholars began to look at legal institutions as a possible determinant factor for economic growth. An initial observation shows stark contrasts between the common-law countries and the civil laws. The former generally perform better than the later in terms of growth, capital markets, good governance, and standards of living. However, it was not until the publication of the influential article "Law and Finance" by La Porta, Lopez-de-Silanes, Shleifer, and Vishny (hereafter "LLSV") in 1998 that scholars began to investigate the extent to which different legal traditions would lead to the divergence of macro-economic outcomes. ${ }^{17}$

LLSV's cross-country studies show the importance of legal rules for understanding the divergence incomes among countries. LLSV and the subsequent "legal origin" literatures advocate the view that common law institutions are intrinsically superior compared to the civil law system, which in turn results in higher economic development. They attribute these outcomes to the effect of intrinsic advantages of institutional designs in common law systems. Common law countries are seen to provide more flexibility and better protection for foreign investors against insider abuse in the corporate sector, ${ }^{18}$ tend to regulate less, particularly in labor-related issues and industrial sectors, ${ }^{19}$ and give more property rights protection. ${ }^{20}$

Situating against this backdrop, Milhaupt and Pistor's book, Law and Capitalism contributes to the debate on the exogenous effect of legal institutions on key economic outcomes. They offer a fundamental and consequential rebuke against the current prevailing view on how law affects the economy. Their starting point is the recognition of the dynamic nature of laws that constantly adapts to meet changing market needs, instead of treating law as static, fixed exogenous entities.

The authors start by challenging the current prevailing view on the relationship between law and capitalism. For example, they criticize LLSV for not differentiating between countries that voluntarily develop their legal systems from those that involuntary adopt the law through legal transplantation. The authors argue that if this "transplant effect" is introduced in cross-country regressions, the LLSV's statistical result will be insignificant. They further argue that the current framework suffers from oversimplification of the complex dynamic in which real-world economy and legal

${ }^{16}$ Clarke, “Corporate Governance”, p. 7.

17 Rafael La Porta, Florencio Lopez-de-Silanes, Andrei Shleifer, and Robert W. Vishny, "Law and Finance," Journal of Political Economy 106 (1998), pp. 1113-55.

${ }^{18}$ Ibid.; See also Simeon Djankov, Rafael La Porta, Florencio Lopez-de-Silanes, Andrei Shleifer, "The law and economics of self-dealing," Journal of Financial Economics 88 (2008), pp. 430-65.

19 See Juan C. Botero, Simeon Djankov, Rafael La Porta, Florencio Lopez-de-Silanes and Andrei Shleifer, “The Regulation of Labor", The Quarterly Journal of Economics 119, no. 4 (2004), pp. 1339-82.

20 See Simeon Djankov, Edward Glaeser, Rafael La Porta, Florencio Lopez-de-Silanes, and Andrei Shleifer, "The New Comparative Economics," Journal of Comparative Economics 31 (2003), pp.595-619; See also Mohammad Amin and Jamal Ibrahim Haidar, "The Cost of Registering Property: Does Legal Origin Matter?," Empirical Economics 42, no. 3 (2012), pp. 1035-50. 
systems operate. More importantly, it could not explain the existence of high numbers of anomaly countries that enjoy rapid economic development despite coming from civil law traditions such as China, South Korea, and Taiwan. Likewise, legal traditions alone could not help to explaining economic failures and underdevelopment in some common law countries in Africa such as Nigeria and Zimbabwe.

The authors further propose an alternative framework for understanding the relationship between law and capitalism by recognizing the diversity and the dynamic nature of legal systems. According to the authors, each legal system has its own costs and benefits, and thus has equal opportunity to provide the country with environment conducive for economic success. Furthermore, the authors emphasize three different functions played by law in support of market (i.e. protection, coordination, and expression). In other words, protecting property rights is only one possible function of law. Other important functions of law are for coordinating among shareholders and providing important signals to market actors regarding the credibility of government policies. Lastly, the authors stress the importance of analyzing the demand for law and the process of legal development, and adaptation of law to the needs of the marketplace.

In Part II the authors apply the analytical framework on six recent corporate controversies and examine the way in which major stakeholders in each case respond to the crisis and reshape the law accordingly. These cases include: the Enron scandal and the enactment of Sarbanes-Oxley Act in the United States (chapter 3); the Mannesmann executive compensation scandal and criminal trial in Germany (chapter 4); the hostile takeover by Livedoor and the adoption of guidelines for takeover defense in Japan (chapter 5); the scandal involving the SK group (one of Korean chaebols/business groups) and insurgency by foreign institutional investors in South Korea (chapter 6); the insider trading and false disclosure scandal of Chinese stateowned aviation oil firm listed in Singapore and Chinese-Singapore dispute resolution (chapter 7); and Yukos renationalization case and the struggle for control over natural resources in Russia (chapter 8). These cases allow the authors to gauge the dynamic interplay among law, markets, and the political economy within a particular system.

Overall, this book offers a compelling account on the interrelationship between laws and market economies. The authors reject legal determinists assumption of "legal origin" literatures that attribute the superiority of common law systems compared to their civil law counterparts, solely to their legal traditions. They directly challenge the mainstream literatures that treat law as an exogenous factor, a fixed societal endowment that helps to determine economic outcomes. Instead, they focus on different functions and forms of legal systems and how they change over time, in order to better understand how law actually shapes and twits markets.

One of its major contributions is the new framework that the authors propose to classify legal system around the world beyond the conventional distinction of common law versus civil law systems. By using two exes in the matrix (decentralized vs. centralized and coordinative vs. protective), the authors can capture both interest group (the demand side) and political actors (the supply side) into the analysis of the interrelationship between the law and the economic systems. The distinction between coordinative-centralized and protective-decentralized legal systems is particularly helpful in understanding countries that belong to the same legal traditions yet show a very different level of government intervention in the market such as the United States and Singapore. Singaporean government play major roles in coordinating markets, in 
contrast to the American system that is highly decentralized in the way that private actors play more role in enforcing rules and protecting their rights. Moreover, the case studies nicely illustrate the different nuances of the authors' proposed legal systems framework. For example, the contrast between Russia and China reflects that the form of government does not determine whether power is centralized or decentralized. Even though Russia applies federal system, its authority is highly centralized, and even so than China's unitary system. The sample of case studies also depicts varieties of advance market-oriented economies, representing various types of capitalism across different types of regime.

Despite its virtue, the book is open to a few criticisms. One major shortcoming in the author's approach is their little attention to the history of modern economic development in each case they examine. In some cases, the authors take their sources at face value. One criticism put forward by Ohnersorge is that the authors provide a rather one-sided story of a corporate scandal. For example, in the Japanese case, Ohnersorge criticizes the authors for not mentioning the other version of the story, especially when "reputable authorities" dispute an aspect of the author's account. ${ }^{21}$

Furthermore, the author's aim at capturing multiple functions of law and the complexity of real-world governance system sacrifices a good deal of parsimonious theory building. Because the authors try to catch many different things at once, their theory suffers from clear causal inference, mechanism and generalization. The authors, indeed, reject generalization of their theory by intentionally avoid statistical analysis of large-n data sets, and instead focus on detailed discussions of narrow sets of case studies of current corporate governance scandals in large economies. Consequently, the authors failed to engage their theory in the broader debate over the role of law for economic development.

Despite these shortcomings, the authors have provided a useful hint for policymakers pursuing legal reforms in developing countries. One important lesson learned from the book is that there is no panacea for anything. Effort at reforming legal institutions and fostering market economies should not focus solely on importing or adopting "good laws" that work in other places. The authors argue any attempt at transplanting legal institutions should take into account various domestic factors including internal dynamics among legal apparatus (lawyer, judges, and state apparatus) and legal enforcement. Moreover, legal transplants have higher possibility to succeed if the forthcoming laws are well suited with the existing system and match with the dominant function as well as organization in that country. In other words, law is not a technology that simply can be borrowed or adopted to serve particular functions without considering domestic factors that could support the successful implementation of such law. Indeed, important problems in real world tend to be complex and, thus, the implementation of "good laws" alone could not guarantee good economic outcomes.

${ }^{21}$ John Ohnesorge, "Curtis Milhaupt and Katharina Pistor, Law \& Capitalism: What Corporate Crises Reveal About Legal Systems and Economic Development Around the World. Book Review," The American Journal of Comparative Law 57, no. 4 (Fall, 2009), pp. 943-947. 


\section{CORPORATE GOVERNANCE FAILURE OR SUPERVISORY FAILURE? A CASE STUDY: BANK CENTURY BAILOUT}

The impact of the recent Global Financial Crisis on Indonesia's economy is relatively mild compared to that of the 1997-1998 Asian Monetary Crisis. One of the reasons is because financial market contributes only to small percentage of Indonesia's GDP, while the largest percentage is domestic consumption. Furthermore, Indonesia financial sectors have been less vulnerable to external shocks as a result of strengthened rules and regulations by Bank of Indonesia.

Nevertheless, Indonesia's banking and financial institutions could not escape from the domino effect of the global crisis. "The level of Indonesia's credit default swap (CDS), which in normal times hovered in the range of 200 basis points, rose to $1,48.4$ basis points, 400 points higher than that of the Philippines, which in normal times had a CDS level equal to that of Indonesia." (Tempo, September 2009). Loss of confidence in the banking and financial sectors led to large capital withdrawal because Indonesia is increasingly seen as an unsafe place to save money particularly after the liquidation of Bank Indover, owned mostly by Bank Indonesia.

Under these circumstances, 2008 marks yet a scandalous bailout bank involving key political figures and the ruling party. It was the second largest banking scandal after the Bank Indonesia Liquidity Assistance Program that involves 600 trillion rupiah of state funds following the crisis in 1999. Founded by the Tantular Family in 1989, Bank Century was a product of merger among Bank CIC International, Bank Danpac, and Bank Pikko in 2005. Bank Century was at a brink of collapse before the Central Bank decided to bail it out in 2008. The government took over the bank after it declared itself insolvent in November 2008 by injecting capital through the Saving Guarantee Board (LPS).The government categorized the Bank Century as "failed bank with systemic impact." The assessment as to whether the Bank Century will have a systemic effect on the national economy was made by the Finance Sector Committee (KSSK), comprising technocrats such as the Bank Indonesia Governor Boediono (the then vice president) and the Finance Minister Sri Mulyani (the then managing director at the World Bank, and the current Finance Minister under Widodo's Working Cabinet or Kabinet Karya). The committee justified the bailout as a necessary step to prevent panic among depositors of other bank and to further prevent a domino effect of a more disastrous crisis amid the unstable domestic economy and the unfolding global financial crisis. This decision is also taken partly due to the fear that the effect of the 1997 Asian Monetary crisis - when the government closed down 16 banks will reappear and hit the country's economy again (Tempo, September 2009). The global financial crisis triggered by the collapse of Lehman Brothers and other major international banks further reaffirm the government belief that it is better to save the bank to prevent a bigger chaos.

A financial authority says, "it is only natural that the government elected to rescue Bank Century in which only an estimated Rp600 billion was needed to keep the bank afloat. Liquidating the bank would cost the government close to Rp7 trillion" (Tempo, September 2009). At that time, there was fear that the closing of Bank Century would trigger bank rushes that could potentially collapse 23 other banks. Bank Indonesia monitored that "on November 10, 2008, funds withdrawn amounted to Rp1.1 trillion and continued up until the closure of Bank Century. The total third party funds in these 18 banks declined by more than Rp14 trillion." If this condition persisted, it could have distrusted the payment system and could also have had a negative effect on 
the financial markets. Bank Indonesia concluded that Bank Century had to be rescued immediately to prevent a systematic effect on other banks (Tempo, September 2009).

But this is not the end of the story. The problem was that the capital injection for Bank Century had rocketed to four times of the original amount. The bailout money required to save Bank Century quadruple from 632 billion rupiah (US\$70.9 million) as of November 2008, to over 6.76 trillion (US\$677.4 million) (Tempo, September 2009). There were evidently huge fraud and embezzlement by major shareholders of Bank Century involving hundreds of millions of dollars of taxpayers' money. Robert Tantular, the owner of Bank Century, "along with three directors has been arrested" for fraud allegations. The three directors has arrested and tried. "Former chief executive Hermanus Hasan Muslim was sentenced to three years in jail and a Rp5 billion fine, former treasury director Laurens Kusuma faced four years in jail, and Robert Tantular eight years in jail and a Rp50 billion fine. Others, including two shareholders, are still at large and on Interpol's wanted list" (Tempo, September 2009).

\section{The Chronology of Bank Century Bail Out ${ }^{22}$}

"On Thursday night, November 20, 2008, Governor of Bank Indonesia, Boediono, together with members of the KSSK members met to decide the fate of bank Century, which had been hit by liquidity difficulties. The meeting concluded that Bank Century had to be saved. It was estimated that capital needs of Bank Century was assessed at around Rp632 billion. However this figure could change because checks and investment audits were not yet complete. Two days after the meeting, LPS injected capital amounting to Rp632 billion. By that time, however, Bank Century's requirements had already increased to Rp2.7 trillion. LPS added capital injections on three more occasions. On December 5, 2008, Bank Century received an "infusion" of Rp2.2 trillion in order to increase liquidity. On February 3, 2009, another injection of Rp1.55 trillion was given as additional capital. On July 21, once gain Bank Century received another injection of Rp630 billion for additional capital. These capital injections were made in stages because the assessment results from Bank Indonesia were issued in stages. Here was the beginning of the problem. As a result, explanations about the funding needs for Bank Century became piecemeal and incomplete. In stages, investigators uncovered a fictitious letter of credit $(L / C)$ worth US\$197 million, non-performing loans worth Rp1 trillion, and suspected fraudulent use of founds amounting to about US\$18 million. Bank Century bonds no longer have any value. It was these conditions that made the capital adequacy ration (CAR) of Bank Century decline slowly."

${ }^{22}$ Tempo English Edition, September 8 -14, 2009, "Bailing Out Bank Century.” 
Table 1.

Funds Required to Rescue Bank Century

*Rp Billions, **KAP Audit

\begin{tabular}{|c|c|c|c|}
\hline Balance Sheet & Assessment & CAR (1\%) & Capital Requirement* \\
\hline $10 / 31 / 2008$ & $11 / 20 / 2008$ & -3.53 & 632 \\
\hline $11 / 20 / 2008$ & $11 / 23 / 2008$ & -35.53 & 2,655 \\
\hline $12 / 31 / 2008$ & $01 / 27 / 2009$ & -19.21 & 2,201 \\
\hline $12 / 31 / 2008$ & $03 / 31 / 2009$ & -22.29 & $1,1550^{* *}$ \\
\hline $06 / 30 / 2009$ & $07 / 24 / 2009$ & 8 & 6,762 \\
\hline
\end{tabular}

Source: Bank Indonesia from Tempo, p. 42

With the large amount of capital injections involved in the bailout, Bank Century quickly escalated into a scandal and entered the political arena. This became a highly contested issue among politicians and the center of public attention. The House of Representatives were questioning why the capital injection for Bank Century ballooned up to Rp6.7 trillion. Many suspect the decision to save the bank lacked any legal basis. As the case proceeded, however, the scandal became more and more politicized, targeting the ruling party and the cabinet members. As Tempo Magazine reported, "The Bank Century issues seem to be hitting both Sri Mulyani and Boediono in the run-up to the formulation of the new cabinet. The aim is so that Sri Mulyani no longer has a chance of becoming Finance Minister. Several of her policies have not been acceptable to the parliament members" (Tempo, September 2009).

Despite the political issues, the Bank Century scandal highlights the lax regulation and supervision in banking and financial sectors. The Central Bank was accused of being lax in applying its own regulations on the violations committed by Bank Century prior the bailout. It was blamed for the approval for the merger of banks CIC, Danpac, and Pikko to became Bank Century in 2005. The Audit Board of the Republic of Indonesia (BPK) reported, "Bank Indonesia had been negligent in setting the conditions for the acquisition and merger. The acquisition of Danpac and Pikko by Chinkara Capital violated Bank Indonesia regulations because many of the conditions had not been met. For example, the acquisition plan had not yet been published in the newspaper, Chinkara could not produce its financial reports for the past three years, and the recommendation from Chinkara's home country in the Bahamas was unclear." (Tempo, December 2009). These facts were evidently ignored by Bank Indonesia that approved the merger of Danpac, Pikko, and CIC into Bank Century in early December 2005.

According to the BPK, "the authorization of the merger was facilitated by a note from the director of the Bank Indonesia's Directorate Supervision 1. Among other things, Bank Indonesia changed the status of Chinkara's securities from default to performing. As a result, Chinkara appeared to had met the condition of deposit capital and the 8 percent of capital adequacy ratio (CAR)." The Central Bank supervision director allegedly said that despite many irregularities conducted by Chinkara, it was still better to merge it with several other banks so that the Bank Indonesia could "control them more strictly" (Tempo, December 2009). 
It was later proved that the decision to merge the three banks was a bad decision. A year after the merger, Bank Century faced problems with liquidity and capitalization due to its low-quality securities. It also violated the maximum limit for issuing credit and the net position on foreign currencies and its capital adequacy ratio sunk at minus 132.58 percent by February 28, 2005. These problems led Bank Indonesia to put Bank Century under an intensive supervision on October 2005, and later under special supervision on November 6, 2008. During the supervision period, Bank Indonesia repeatedly warned the management of Bank Century to resolve its liquidity and capitalization problem by looking for new investors.

However, it turned out that Bank Century condition worsened. Before finding any new investors, Bank Century was already unstable and in near-collapse. The move by Bank Indonesia to put it under special supervision was ineffective." Bank Century had to be injected with Rp6.7 trillion of funds from the government (Tempo, December 2009).

\section{CONCLUSION}

The financial crisis started in 2007 has led to a global phenomena resulting in banking and other financial institutional failures including those in Indonesia. The failure of Bank Century in late 2008 forced the government to bailout the bank in order to prevent a systemic effect on other banks that would further detriment the country's financial stability and the economy. As in many parts of the world, the financial crisis in Indonesia highlights the issues of corporate governance characterized by lack of regulations and supervision in the banking and financial sectors.

On a theoretical level, this finding can be extended to ask different research questions beyond the corporate governance issue such as, what are the impacts of corporate scandals for policy reform? Do crises affect country with different regime differently? According to Milhaupt and Pistor's matrix, in decentralized - protective governance system, corporate scandals might lead to a more massive public opinion demanding for reform. The decentralized system provides private actors with more opportunities to channeling their opinion and demands, and will be likely accelerating the reform processes. On the other hand, in a centralized - coordinative system, one would not expect demands for reform to come through the same channels, because the different character of the regime. In such system, legal reform will be more likely occurred as bargaining products between interest groups and state officials, without massive participation by ordinary citizens.

In this regard, Rosas ${ }^{23}$ and Satyanath ${ }^{24}$ studies on the role political regime in relation to banking crisis are particularly interesting. Rosas argues that the types of response to banking crisis will depend on the types of government or political regime. In the case of banking crisis, government in a democratic country will be more likely to take more limited interventions in the banking sectors than the non-democratic ones. Electoral accountability constraints policy-makers to apply costly and unpopular policies such as bail out banks. This "democratic effect", according to Rosas, is what makes authoritarian governments are more prone to bail out banks compared to those in democracy. Rosas contrasts the divergence response in Argentina (as democratic

${ }^{23}$ Guillermo Rosas, Curbing Bailouts: Bank Crises and Democratic Accountability in Comparative Perspective (Ann Arbor: The University of Michigan Press, 2009).

24 Satyanath, Shanker, Globalization, Politics, and Financial Turmoil. Asia's Banking Crisis (New York: Cambridge University Press, 2006) 
country) and Mexico (as semi-authoritarian) and attributes such divergence to their types of regime.

Contrary to Rosas, Satyanath argues against the positive effect of democracy in times of financial crises. Instead, she argues that under several conditions democracy could have detrimental consequences on financial crises. Using a game theory framework, she examines the political environment leads to the 1998 Asia's financial crisis and finds that democracy had caused "the signaling problem" in developing countries making them especially vulnerable to crisis. Checks and balances and accountability mechanism in a democratic country force the executives to appoint cabinet members based on merit, rather than personal ties or connection. Democracy reduces the freedom for political leaders to appoint "an official who shares his regulatory preferences" and thus will reduces the likelihood of credible communication of financial information. She contends that miscommunication between the financial officials and the chief executive as a causal factor contributing to financial crisis.

On a practical level, this study further reaffirms the previous literatures that highlights the needs for more government intervention through regulatory measures and policies in the banking and financial sectors. A stringent prudential bank regulation, defined as "environments where regulators enforce strict rules aimed at safeguarding the solvency of banks" 25 is particularly critical for preventing moral hazards and irregularities following a bail out. Furthermore, a stronger legal enforcement is needed to ensure that taxpayers' money that are injected to a fail bank would not go into personal pockets of the shareholders.

${ }^{25}$ B. Eichengreen, “Capital Controls: Capital Idea or Capital Folly?," 2008, http:// emlab.berkeley.edu/ users/eichengr/capcontrols.pdf, accessed 11 January 2016. 


\section{Bibliography}

\section{Books}

Friedman, L. "Legal Culture and the Welfare State." In Dilemmas of Law in the Welfare State, edited by Gunther Teubner, 13-27. Berlin: de Gruyter, 1986.

Hayek, F.A. Law, Legislation and Liberty: Rules and Order. Volume 1. Chicago: Unversity of Chicago Press, 1978.

Independent Evaluation Office (IEO). The IMF and Recent Capital Account Crises: Indonesia, Korea, Brazil. Evaluation Report, International Monetary Fund, 2003.

Milhaupt, Curtis J. and Katharina Pistor. Law and Capitalism: What Corporate Crises Reveals about Legal Systems and Economic Development Around the World. Chicago: the University of Chicago Press, 2008.

Nidhiprabha, Bhanupong. "The Global Financial Crisis and Macroeconomic Policy in Southeast Asia." In Routledge Handbook of Southeast Asian Economics, edited by Ian Coxhead, 385-407. New York: Routledge, 2015.

Nonet, Phillipe dan Philip Selznick, Law and Society in Transition: Toward Responsive Law. New York: Harper and Row, 1978.

North, D.C. Institutions, Institutional Change and Economic Performance. New York: Cambridge University Press, 1990.

Pepinsky, Thomas B. Economic Crises and the Breakdown of Authoritarian Regimes: Indonesia and Malaysia in Comparative Perspective. Cambridge University Press, 2009.

Polanyi, Karl. The Great Transformation: The Political and Economic Origins of our Time. Boston: Beacon Press, 1944.

Rosas, Guillermo. Curbing Bailouts: Bank Crises and Democratic Accountability in Comparative Perspective. Ann Arbor: The University of Michigan Press, 2009.

Satyanath, Shanker, Globalization, Politics, and Financial Turmoil. Asia's Banking Crisis. New York: Cambridge University Press, 2006.

Sorkin, Andrew Ross. Too Big to Fail: The Inside Story of How Wall Street and Washington Fought to Save the Financial System - and Themselves. New York: The Penguin Groups, 2009.

Sun, William, Jim Stewart, and David Pollard. Corporate Governance and the Global Financial Crisis: International Perspective. Cambridge University Press, 2011.

Tucker, Robert C. ed. Marx-Engels Reader. Second Edition. W. W. Norton \& Company; 1978.

Visser, W. "CSR 2.0: From the Age of Greed to the Age of Responsibility." In Reframing Corporate Social Responsibility: Lessons from the Global Financial Crisis, edited by William Sun, J. Stewart, D. Pollard,

Visser, W. "CSR 2.0: From The Age of Greed To The Age of Responsibility.” In Reframing Corporate Social Responsibility: Lessons from the Global Financial Crisis, eds. Sun, W., Stewart, J. and D. Pollard, 231-251. Bingley: Emerald Group 
Publishing, 2010.

\section{Articles}

Amin, Mohammad and Jamal Ibrahim Haidar. "The Cost of Registering Property: Does Legal Origin Matter?" Empirical Economics 42, no. 3 (2012): 1035-50.

Botero, Juan C., Simeon Djankov, Rafael La Porta, Florencio Lopez-de-Silanes and Andrei Shleifer. "The Regulation of Labor." The Quarterly Journal of Economics 119, no. 4 (2004): 1339-82.

Djankov, S., La Porta, R., Lopez-de-Silanes, F. and Shleifer, A. “Courts.” Quarterly Journal of Economics. 118 (2003): 453-517.

_-_ , Edward Glaeser, Rafael La Porta, Florencio Lopez-de-Silanes, and Andrei Shleifer. "The New Comparative Economics." Journal of Comparative Economics 31 (2003): 595-619

_- - Rafael La Porta, Florencio Lopez-de-Silanes, and Andrei Shleifer. "The law and economics of self-dealing." Journal of Financial Economics 88 (2008): 430-65.

Glaeser, E. and Shleifer, A. "Legal origins." Quarterly Journal of Economics 117 (2002): 1193-1230.

La Porta, R., Lopez-de-Silanes, F. and Shleifer, A. “The Economic Consequences of Legal Origins." Journal of Economic Literature 46 (2008): 285-322.

_- - Lopez-de-Silanes, F., Shleifer, A. and Vishny, R. "Law and Finance." Journal of Political Economy 106 (1998): 1113-1155.

_-_, Florencio Lopez-de-Silanes, Andrei Shleifer, and Robert W. Vishny. "Law and Finance." Journal of Political Economy 106 (1998): 1113-55.

Mahoney, P.G. "The Common Law and Economic Growth: Hayek Might be Right." Journal of Legal Studies 30 (2001): 503-525.

Ohnesorge, John. "Curtis Milhaupt and Katharina Pistor, Law \& Capitalism: What Corporate Crises Reveal About Legal Systems and Economic Development Around the World. Book Review." The American Journal of Comparative Law 57, no. 4, (Fall 2009): 943-947.

Schumpeter, Joseph A. Capitalism, Socialism and Democracy, Third Edition. New York: Harper \& Row, 1950.

Skeel Jr., David A. "Governance in the Ruins." Harvard Law Review 122, no. 2 (Dec 2008): 696-743.

Tempo English Edition, December 1 - 7, 2009, "Cracking the Century Case."

_-_, September 8 -14, 2009, "Bailing Out Bank Century."

The Economist, September 10, 2009.

Trubek, David M. "Max Weber on Law and the Rise of Capitalism." Wisconsin Law Review (1972): 720-753.

\section{Websites}

Eichengreen, B. "Capital Controls: Capital Idea or Capital Folly?" http://emlab. 
berkeley.edu/users/eichengr/capcontrols.pdf. Accessed 10 January 2011.

Enoch, Charles. "Interventions in Banks During Banking Crises: the Experience of Indonesia." IMF Policy Discussion Paper PDP/00/2, https://www.imf. org/external/pubs/ft/pdp/2000/pdp02.pdf. Accessed 10 January 2011.

Harvey, Mark and Stan Metcalfe. "The Ordering Of Change: Polanyi, Schumpeter and The Nature Of The Market Mechanism." Discussion Paper 70 March 2005, CRIC University Of Manchester, http://repository.essex. ac.uk/10408/1/polyani_schumpeter_amrket.pdf. Accessed 10 January 2011.

Lietaer, Bernard, Robert Ulanowicz, and Sally Goerner. "White Paper on All the Options for Managing a Systemic Bank Crisis." http://www.lietaer.com/ images/White Paper on Systemic Banking Crises final.pdf. Accessed 10 January 2011.

The OECD Steering Group on Corporate Governance. Corporate governance and The Financial Crisis: Key Findings and Main Messages. Report of June 2009 http://www.oecd.org/dataoecd/3/10/43056196.pdf. Accessed 10 January 2011. 